\title{
Role of transforming growth factor $\beta 1$ in the inhibition of gastric cancer cell proliferation by melatonin in vitro and in vivo
}

\author{
HUI LIU ${ }^{1-4}$, YU ZHU ${ }^{1-3}$, HUI ZHU ${ }^{1-3}$, RONG CAI $^{1-4}$, KAI-FANG WANG $^{1-4}$, \\ $\mathrm{JUN} \mathrm{SONG}^{3-5}$, RI-XIONG WANG ${ }^{6}$ and RUI-XIANG ZHOU ${ }^{1-4}$ \\ ${ }^{1}$ Department of Human Anatomy, Histology and Embryology, ${ }^{2}$ Key Laboratory of Stem Cell Engineering and \\ Regenerative Medicine, ${ }^{3}$ School of Basic Medical Sciences, ${ }^{4}$ Key Laboratory of Gastrointestinal Cancer, \\ Fujian Medical University, Ministry of Education, ${ }^{5}$ Department of Cell Biology and Genetics, \\ ${ }^{6}$ Department of Chemotherapy, The First Affiliated Hospital, \\ Fujian Medical University, Fuzhou, Fujian 350122, P.R. China
}

Received November 19, 2018; Accepted May 13, 2019

DOI: 10.3892/or.2019.7190

\begin{abstract}
Transforming growth factor $\beta$ (TGF- $\beta$ ) is a polypeptide growth factor with various biological activities, and is widely distributed in various tissues. In mammals, TGF- $\beta$ has three isoforms: TGF- $\beta 1,2$, and 3, of which TGF- $\beta 1$ is most abundant in the TGF- $\beta$ family. TGF- $\beta 1$ is closely related to the occurrence and development of tumors. A large number of previous studies have shown that melatonin can inhibit a variety of malignancies. Thus, the aim of the present study was to investigate the role of TGF- $\beta 1$ in the melatonin-mediated inhibition of the proliferation of gastric cancer cells in vitro and in vivo. TGF- $\beta 1$ cytokine stimulation, anti-TGF- $\beta 1$ neutralizing antibody blocking, siRNA TGF- $\beta 1$ and other means were utilized to explore the role of TGF- $\beta 1$ during the course of anti-gastric cancer by melatonin. The results showed that melatonin upregulated the expression of TGF- $\beta 1$ in tumor tissues during the process of inhibiting gastric cancer tumor growth in vivo. Melatonin inhibited the proliferation of gastric cancer cells in vitro, accompanied by increased expression of TGF- $\beta 1$ in a time-dependent manner. siRNA-mediated silencing of TGF- $\beta 1$ and anti-TGF- $\beta 1$ neutralizing antibody completely blocked the TGF- $\beta 1$ pathway, which significantly antagonized the melatonin-mediated inhibition of the growth and proliferation of gastric cancer cells, and promoted G1 phase to $\mathrm{S}$ phase transformation of MFC cells. Our findings suggest that TGF- $\beta 1$ is involved in the regulation of the proliferation of tumor cells. One of the ways in which melatonin inhibits the proliferation of gastric cancer cells is dependent on the TGF- $\beta 1$ signaling pathway.
\end{abstract}

Correspondence to: Dr Rui-Xiang Zhou, School of Basic Medical Sciences, Fujian Medical University, 1 Xueyuan Road, Fuzhou, Fujian 350122, P.R. China

E-mail: zhourx@mail.fjmu.edu.cn

Key words: gastric cancer, melatonin, TGF- $\beta 1$

\section{Introduction}

Gastric cancer is the fifth most common malignancy, and the third leading cause of cancer-related death worldwide, with approximately 952,000 new cases and 723,000 deaths per year. It is most prevalent in East Asia. The occurrence and development of gastric cancer is a multi-stage, multi-step process, which is the result of accumulation of multiple genetic variants $(1,2)$.

Melatonin ( $N$-acetyl 5-methoxytryptamine, MLT) is a neuroendocrine hormone synthesized and secreted mainly by the pineal gland. MLT is also synthesized in some peripheral organs including gastrointestinal organs (3) and skin $(4,5)$, with higher levels than that noted in the serum. MLT exerts a variety of receptor-mediated or receptor-independent physiological functions (6): Regulation of the circadian rhythm, inhibition of the development of the reproductive system, regulation of bone growth, inhibition of tumorigenesis, regulation of the immune system, scavenging of free radical antioxidants, and exhibition of anti-inflammatory and neuroprotective effects (5,7-9). A large number of studies have shown that MLT can inhibit a variety of malignancies such as gastric (10), liver (11), breast (12) and oral cancer (13) by promoting tumor cell apoptosis, arresting the cell cycle, inhibiting proliferation, regulating antitumor immunity, scavenging free radicals, and competitively inhibiting estrogen receptors. Our previous experiments established the different concentrations of MLT which were able to intervene in a murine model of gastric cancer, and it was found that MLT reduced tumor volume and weight, achieved antitumor effects, and directly downregulated $\mathrm{CD} 4{ }^{+} \mathrm{CD} 25^{+}$Treg cells and Foxp3 expression in gastric cancer tissue (14). Different concentrations of MLT have been found to inhibit the proliferation of human gastric cancer cell lines MGC-803, SGC-7901 (15) and AGS (16), and the murine gastric cancer MFC cell line (14) in a time-dose dependent manner. Selective addition of Treg cells or CD4 ${ }^{+} \mathrm{CD} 25^{-} \mathrm{T}$ cells to co-cultures revealed that MLT inhibited the proliferation of MFC gastric cancer cells in a dose-dependent manner (17).

Transforming growth factor $\beta$ (TGF- $\beta$ ) is a polypeptide growth factor with various biological activities, and is widely 
distributed in various types of tissues. In mammals, TGF- $\beta$ has three isoforms: TGF- $\beta 1,2$ and 3 , of which TGF- $\beta 1$ is most abundant in the TGF- $\beta$ family (18). The role of TGF- $\beta$ in the development of tumors is dual. Initially, it inhibits the growth of tumor cells; however, when tumor cells lose their sensitivity it promotes tumor cell growth by affecting the extracellular matrix, cell adhesion, neovascularization, the immune response, and other aspects of tumor growth (19). Proietti et al (20) found that the expression of TGF- $\beta 1$ in MCF-7 human breast cancer cells was significantly upregulated after MLT intervention for $72 \mathrm{~h}$, and was completely inhibited by an anti-TGF- $\beta 1$ neutralizing antibody, indicating MLT mediates late apoptosis of MCF-7 tumor cells.

However, studies on the effects of MLT on gastric cancer and on the expression of TGF- $\beta 1$ are rare. The present study was constructed as a continuation of previous research $(14-17,21)$. The aim of this study was to investigate the role of TGF- $\beta 1$ in the MLT-mediated inhibition of the proliferation of gastric cancer cells in vitro and in vivo.

\section{Materials and methods}

MFC cell culture. The murine foregastric carcinoma cell line (MFC) derived from strain-615 mice was purchased from the Chinese Academy of Sciences, Shanghai Institute for Biological Science (Shanghai, China). MFC cells were cultured in Roswell Park Memorial Institute (RPMI)-1640 medium supplemented with $10 \%$ fetal bovine serum (FBS). The cells were maintained at $37^{\circ} \mathrm{C}$ in a $5 \% \mathrm{CO}_{2}$ atmosphere in a humidified incubator. The cells were passaged every three days by using trypsin digestion. All cell culture reagents were purchased from Gibco/Invitrogen (Thermo Fisher Scientific, Inc., Waltham, MA, USA).

Experimental animal model design and specimen preparation. Six- to 8-week old inbred strain-615 mice $\left(\mathrm{H}-2 \mathrm{~K}^{\mathrm{k}}\right)$ used in these experiments [specific pathogen-free (SPF) grade, weighing 20-25 g) were purchased from Tianjin Institute of Hematology, The Chinese Academy of Medical Science. The totel number of mice were 50, half were males and half were females. Ethical approval was obtained for the use of animals prior to the start of the study from the Fujian Medical University Animal Welfare and Ethics Committee (FJMUIACUC2018-003), which is located in Fuzhou, Fujian Province, China. All the animals were maintained under laboratory conditions with equal periods of light and dark (08:00-20:00) and the acclimation period was about one week. Then 40 mice were subcutaneously inoculated with $5 \times 10^{4}$ MFC cells under the right axilla. One week after inoculation, the tumor-bearing mice model was successfully established as follows: Group A, normal control mice $(n=10)$; Group B, tumor-bearing control mice with a daily intraperitoneal injection of $100 \mathrm{mg} / \mathrm{kg}$ saline water which included $0.5 \%$ absolute ethanol $(n=10)$; Group C, tumor-bearing mice with saline water daily which included low dosage $25 \mathrm{mg} / \mathrm{kg}$ MLT (Sigma-Aldrich; Merck $\mathrm{KGaA}$ ) and MLT was reconstituted in $0.5 \%$ absolute ethanol $(\mathrm{n}=10)$; Group D, tumor-bearing mice with saline water daily which included medium dosage $50 \mathrm{mg} / \mathrm{kg}$ MLT and MLT was reconstituted in $0.5 \%$ absolute ethanol $(n=10)$; Group E, tumor-bearing mice with saline water daily which included high dosage $100 \mathrm{mg} / \mathrm{kg}$ MLT daily and MLT was reconstituted in $0.5 \%$ absolute ethanol $(n=10)$. MLT was administered to the assigned groups at 17:00 every day for one week by intraperitoneal injection. Peripheral blood and tumor tissue samples were collected one day after the final MLT injection. First, the mice were anesthetized with $2 \%$ pentobarbital sodium, $40 \mathrm{mg} / \mathrm{kg}$, and the route of administration of the anesthetic was intraperitoneal injection, then the peripheral blood was taken. Finally, the mice were euthanized by intraperitoneal injection of $2 \%$ pentobarbital sodium $100 \mathrm{mg} / \mathrm{kg}$ after the longest diameter of the tumor was approximately $20 \mathrm{~mm}$ and the largest tumor volume reached $\sim 0.9 \mathrm{~cm}^{3}$ (14). After the confirmation of death, the skin in the right armpit of the strain-615 mice were cut, and the tumor tissue was stripped completely. Peripheral blood was centrifuged at $3,000 \mathrm{x} \mathrm{g}$ for $8 \mathrm{~min}$, and then the upper serum was aspirated and stored at $-80^{\circ} \mathrm{C}$. The tumor tissues were divided into two parts. One was stored in cryovials and immediately put into liquid nitrogen for subsequent RNA extraction experiments. The other was stored in $4 \%$ paraformaldehyde for subsequent paraffin-embedding experiments.

Cell culture model. MFC cells were seeded at a density of $3 \times 10^{5}$ cells/well in 6 -well plates, $2 \mathrm{ml}$ of medium per well. After cells became adherent, MFC cells were treated with 2 or $4 \mathrm{mM}$ MLT, and the blank control was set up. The concentrations of 2 and $4 \mathrm{mM}$ were determined according to our previous research $(14,21)$. The 2-mM MLT intervention group was observed once daily at six time-points of 24-144 h, while the 4-mM MLT intervention group was observed at three daily time-points of 24-72 h. The experiment was repeated at least thrice.

Real-time quantitative RT-PCR for detection of TGF- $\beta 1$ mRNA expression in tumor tissues and MFC cells. Total RNA was isolated using TRIzol reagent (Invitrogen; Thermo Fisher Scientific, Inc.) according to the manufacturer's instructions. First-strand cDNA was generated from $2 \mathrm{mg}$ of each RNA preparation by reverse transcription using the First Strand cDNA Synthesis kit (Promega). Real-time quantitative polymerase chain reaction (PCR) for the analysis of tumor tissues and MFC cells for expression of TGF- $\beta 1$ and glyceraldehyde-3-phosphate dehydrogenase (GAPDH) genes and cDNA was amplified using the dye SYBR-Green (Stratagene) on a StepOnePlus Real-Time PCR System (Applied Biosystems; Thermo Fisher Scientific, Inc.). The PCR cycling conditions (40 cycles) were as follows: $30 \mathrm{sec}$ at $95^{\circ} \mathrm{C}$; for $1 \mathrm{~min}$ at $60^{\circ} \mathrm{C}$. The fold-change in expression of each gene was calculated using the $\left(2^{-\Delta \Delta C q}\right)$ method (22). Product quality of PCR was monitored using post-PCR melting curve analysis at the end of the amplification cycles. The primers were as follows: TGF- $\beta 1$ (213 bp), 5'-AATACAGGGCTTTCGATTCAGC-3' and 5'-TAGTTGGTATCCAGGGCTCTCC-3'; GAPDH (231 bp), 5'-CCGAGAATGGGAAGCTTGTC-3' and 5'-TTCTCGTGG TTCACACCCATC-3'.

Immunohistochemistry to detect TGF- $\beta 1$ expression in tumor tissues and MFC cells. Tumor tissues or MFC cells were fixed with $4 \%$ paraformaldehyde. Immunohistochemistry or immunocytochemical staining method for TGF- $\beta 1$ expression 
was carried out. The sections were incubated at $4{ }^{\circ} \mathrm{C}$ with a primary antibody against TGF- $\beta 1$ (cat. no. ab92486; Abcam; dilution 1:150) overnight. After washing with PBS three times, the sections were incubated with the biotinylated antibody for $1 \mathrm{~h}$, and then incubated in Elite $\mathrm{ABC}$ reagent (Vector Laboratories). Subsequently, the sections were stained with 3,3-diaminobenzidine (DAB, Sigma-Aldrich; Merck KGaA). Images were captured with a Leica DM 4000B photomicroscope (magnification, $\mathrm{x} 400$; Leica Microsystems). Then positive areas of stained cells and average optical, that is, mean optical density of cytoplasm in stained cells were quantified using the image analysis software Image $(\mathrm{NIH}$; National Institutes of Health).

Peripheral serum ELISA assay. Serum was collected as described above, and the TGF- $\beta 1$ protein levels in the serum were quantified by enzyme-linked immunosorbent assay (ELISA) methods. The serum samples were collected and centrifuged at $12,000 \mathrm{x} \mathrm{g}$ at $4^{\circ} \mathrm{C}$ for $10 \mathrm{~min}$, and then ELISA analysis was performed according to the manufacturer's instructions (TGF- $\beta 1$-ELISA kit; Invitrogen; Thermo Fisher Scientific, Inc.). The values of optical density (OD; A450 values) were measured at $450 \mathrm{~nm}$. The standard curve was determined by the SPSS 22.0 statistical software (IBM Corp.) and then the content of TGF- $\beta 1$ was determined in the samples.

Cell proliferation and viability assay. MFC cells were plated into 96-well plates $(5,000$ cells/well). The cells were treated as follows. For the control group, $50 \mathrm{ng} / \mathrm{ml}$ of control solution was added to $100 \mathrm{ng} / \mathrm{ml}$ TGF- $\beta 1$ (PeproTech Inc.) and cultured for 24-144 h. In the cell experimental groups, MFC cells were plated into 96 -well plates $\left(1 \times 10^{4}\right.$ cells/well $)$ and treated as follows: control group, $2 \mathrm{mM}$ MLT + anti-TGF- $\beta 1$ antibody; experimental group, $4 \mathrm{mM}$ MLT + anti-TGF- $\beta 1$ antibody, $1 \mu \mathrm{g} / \mathrm{ml}$ (R\&D Systems), then cultured for $24-144$ or $24-72 \mathrm{~h}$, respectively. Cell viability and proliferation were assayed using a Cell Counting Kit-8 (CCK-8; Tongren Biochemistry) according to the manufacturer's protocol. Briefly, the cells were incubated with a CCK- 8 solution $(10 \mathrm{ml} /$ well) for $1 \mathrm{~h}$ before cell density was determined by measuring the absorbance at $450 \mathrm{~nm}$ using a Varioskan Flash (Thermo Scientific, Inc.).

Cell transfection of TGF- $\beta 1$ siRNA. Different fragments of TGF- $\beta 1$ siRNA and negative control fragments were synthesized by Shanghai GenePharma Co., Ltd. The sequences of siRNA were as follows: NC sense, 5'-UUCUCCGAACGU GUCACGUTT-3' and antisense, 5'-ACGUGACACGUUCGG AGAATT-3'; TGF- $\beta 1-87$ (TGF- $\beta 1$ A) sense, 5'-CGAAGGCAU UACAGUGUUUTT-3' and antisense, 5'-AAACACUGUAAU GCCUUCGTT-3'; TGF- $\beta 1-273$ (TGF- $\beta 1 \mathrm{~B}$ ) sense, 5'-GGG CAGUUACUACAACAUATT-3' and antisense, 5'-UAUGUU GUAGUAACUGCCCTT-3'; TGF- $\beta 1-426$ (TGF- $\beta 1 C$ ) sense, 5'-CACUUAUGCUGAUGGUCUATT-3' and antisense, 5'-UAGACCAUCAGCAUAAGUGTT-3'. MFC cells were seeded in a 6-well plate at a density of $3 \times 10^{5}$ per well, and cultured overnight. Transfection was performed when the cell confluency reached $30-50 \%$, and MFC cells were transfected with siRNA for the negative control (NC) or siRNA TGF- $\beta 1$ using PolyPlus siRNA transfection reagent (Invitrogen; Thermo Fisher Scientific, Inc.) according to the manufacturer's instructions. In brief, siRNA (100 pmol) was mixed with transfection reagent in Opti-MEM serum-free media (Invitrogen; Thermo Fisher Scientific, Inc.) and incubated for $20 \mathrm{~min}$ at room temperature. The siRNA/transfection reagent mixture (TGF- $\beta 1 \mathrm{~A}$ or B or C) was added to the cells for $24 \mathrm{~h}$.

Verification of siRNA interference. The most effective siRNA reagent was selected by real-time quantitative reverse transcription PCR (RT-qPCR) and western blot analysis. After 48 and $72 \mathrm{~h}$ of transfection, total RNA was extracted from each group, and the expression of TGF- $\beta 1$ mRNA was detected by RT-qPCR. The method was the same as that described above. After 48 and $72 \mathrm{~h}$ of transfection, the total protein of each group was extracted. Protein concentrations were measured using the enhanced BCA protein assay kit (Beyotime Institute of Biotechnology) and TGF- $\beta 1$ protein expression was verified by western blot analysis. Equal amounts of $30 \mu \mathrm{g}$ protein were separated by $12 \%$ sodium dodecyl sulfate-polyacrylamide gel electrophoresis $(110 \mathrm{~V}, 1.5 \mathrm{~h})$ and the membranes were blotted by wet transfer $\left(110 \mathrm{~V}, 1.5 \mathrm{~h}, 4^{\circ} \mathrm{C}\right)$ on polyvinylidene fluoride membranes (EMD Millipore). The membranes were blocked in Tris-buffered saline containing $0.5 \%$ bovine serum albumin (BSA). The membranes were then incubated with the primary antibody overnight at $4^{\circ} \mathrm{C}$ : Anti-TGF- $\beta 1$ (cat. no. ab92486; dilution 1:100) and anti- $\beta$-actin (cat.no.ab8227; dilution 1:1,000) (purchased from Abcam). The membranes were washed with Tris-buffered saline Tween-20 (TBST) and then incubated for $2 \mathrm{~h}$ at room temperature with a secondary antibody goat anti-rabbit IgG (cat. no. ab98505; dilution 1:5,000; Abcam). After washing with TBST, the membranes were exposed to X-ray film (1-15 min) for visualization of the immunoreactive bands. Densitometric analysis of specific bands was performed using Quantity One software 4.3.0 (Bio-Rad Laboratories).

Cellular group set-up and viability assay. The cellular experiment was divided into eight groups: 2 or $4 \mathrm{mM}$ MLT-treated groups (a1 or a2), 2 or $4 \mathrm{mM} \mathrm{MLT} \mathrm{+} \mathrm{siRNA}$ negative control groups (b1 or b2), 2 or $4 \mathrm{mM} \mathrm{MLT} \mathrm{+} \mathrm{siRNA}$ TGF- $\beta 1$ groups (c1 or $\mathrm{c} 2$ ) and 2 or $4 \mathrm{mM}$ MLT + siRNA TGF- $\beta 1+$ anti-TGF- $\beta 1$ groups (d1 or d2). Control and a duplicate well were set up and the experiment was performed thrice. For each, $0.25 \mu \mathrm{l}$ Lipofectamine 2000 was diluted with $25 \mu \mathrm{l}$ serum-free medium and incubated for $5 \mathrm{~min}$ at room temperature. Then, $0.25 \mu \mathrm{l}$ siRNA was diluted with $25 \mu 1$ serum-free medium, and the rest of the procedure was the same as above. After the intervention, cells were stimulated with 2 or $4 \mathrm{mM}$ MLT. Then, the absorbance at $450 \mathrm{~nm}$ using a Varioskan Flash (Thermo Scientific, Inc.) was continuously measured 3 times at 24, 48 and $72 \mathrm{~h}$ after dosing.

Propidium iodide (PI) staining. Six-well plated MFC cells were stimulated with 2 or $4 \mathrm{mM}$ MLT. The experiment was divided into the same eight groups as above. Then, the cells were collected at 24, 48 and $72 \mathrm{~h}$ after dosing and stained with propidium iodide (PI; BD Pharmingen; BD Biosciences). PI staining was performed according to the manufacturer's instructions. The cells were collected, and the cells were washed once with PBS, centrifuged at $700 \mathrm{x}$ g for $5 \mathrm{~min}$, and the cells were resuspended in a staining buffer to adjust the cell concentration to approximately $10^{6}$ cells $/ \mathrm{ml}$, then taking 
A a

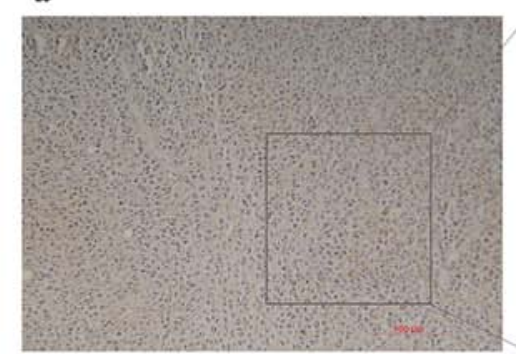

c

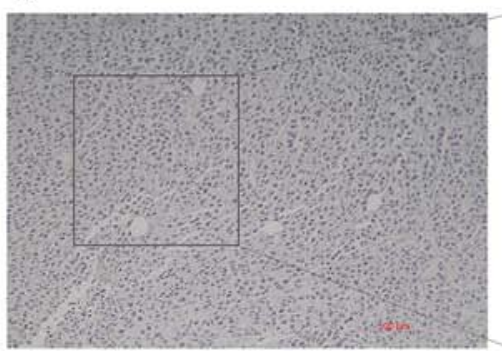

$\mathrm{b}$

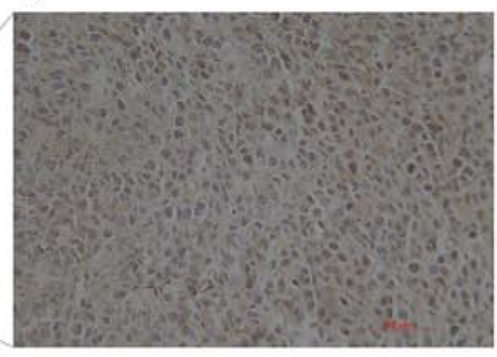

d

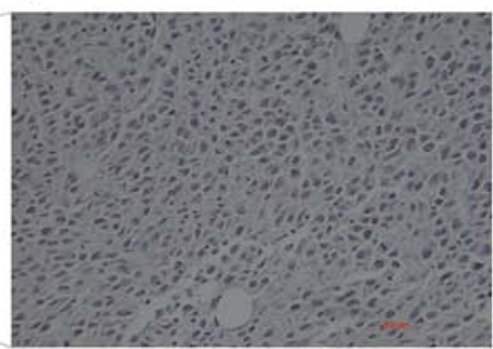

B
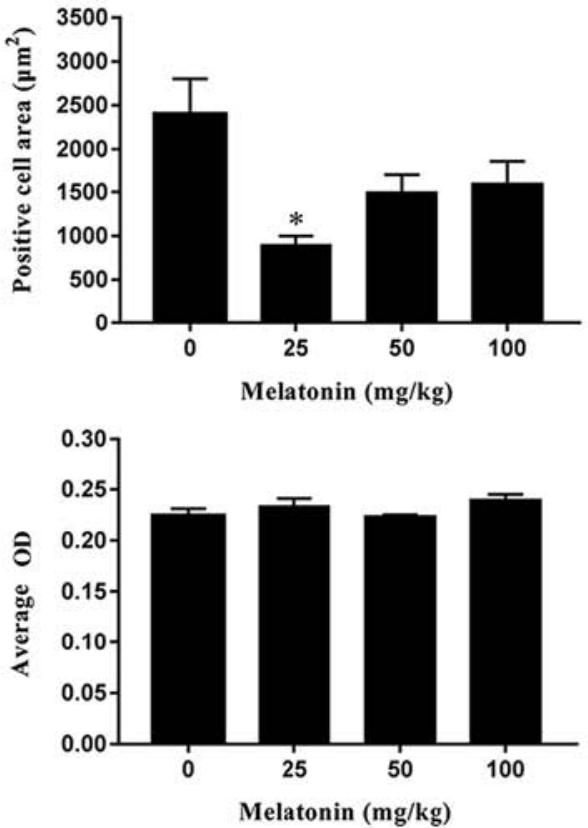

C

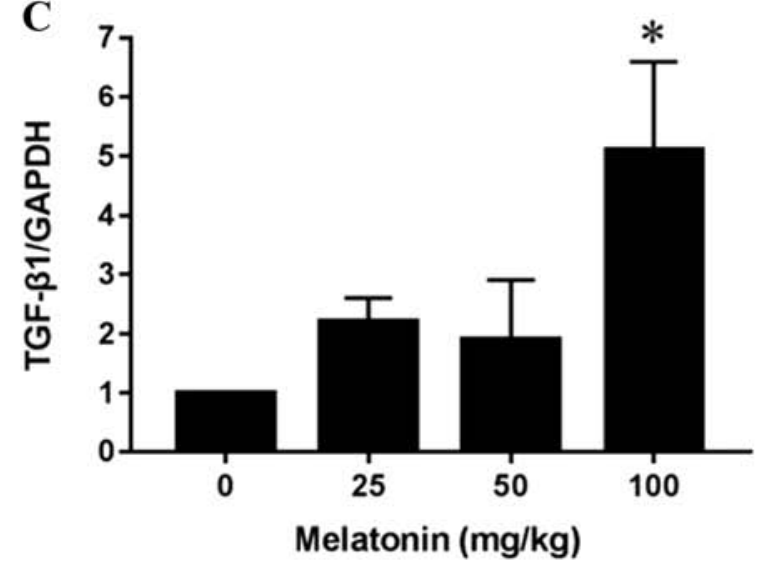

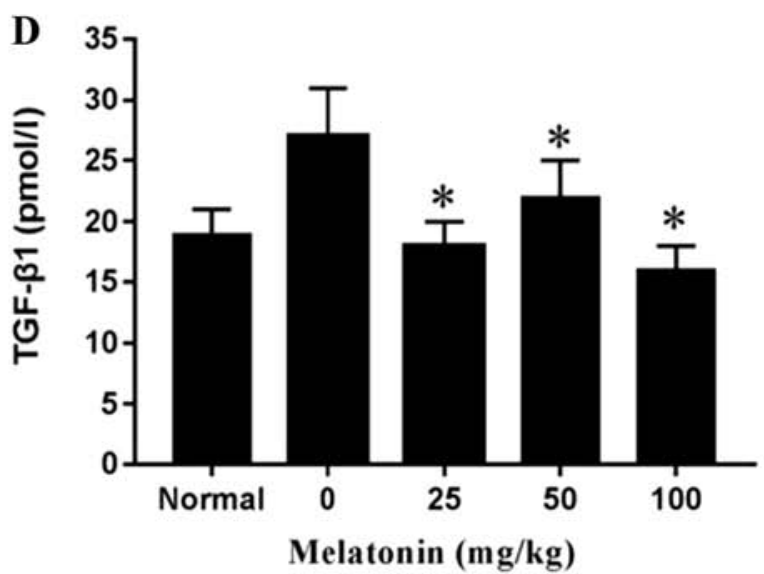

Figure 1. Effect of MLT on TGF- $\beta 1$ expression in MFC cells in vivo. (A) (a and b) Obvious yellow particles (positive expression) in the cytoplasm of tumor cells are shown, and the particles are diffusely or focally distributed (x200 and x400 magnification); (c and d) negative controls (x200 and x400 magnification). (B) Effect of MLT on TGF- $\beta 1$ expression (positive cell area) in the tumor tissues of mice. ${ }^{*} \mathrm{P}<0.05$ vs. the negative control. (C) Effect of MLT on TGF- $\beta 1 \mathrm{mRNA}$ expression (OD) in the tumors of mice. "P<0.05 vs. the negative control. (D) Effect of MLT on the content of TGF- $\beta 1$ in the peripheral serum of mice. ${ }^{*} \mathrm{P}<0.05$ vs. the negative control. MLT, melatonin; TGF- $\beta 1$, transforming growth factor $\beta 1$; mRNA, messenger RNA; OD, optical density.

$100 \mu \mathrm{l}$ of the cell suspension and added $2 \mu \mathrm{l}$ of PI staining dye. This was mixed gently, place at $4^{\circ} \mathrm{C}$ for 5 min in the dark, then the distribution of cells in the three major phases of the cell cycle (G0/G1 vs. S vs. G2) was determined by flow cytometry.

Statistical analysis. Results are presented as the mean values \pm standard error of the mean (SEM), the repeated number of trials of all the experiments was three. ANOVA test was used to compare the difference in mean between multiple groups. The comparison between groups was performed by Bonferroni correction. Differences were considered to be statistically significant at $\mathrm{P}<0.05$. All analyses were performed using SPSS Statistics (Windows), version 22.0 (IBM Corp.).

\section{Results}

Melatonin upregulates the expression of TGF- $\beta 1$ in tumor tissue and downregulates expression in the peripheral serum of gastric cancer-bearing mice. The results showed that TGF- $\beta 1$ expression was positive in the tumor tissues (Fig. 1A), while the area consisting of TGF- $\beta 1$-positive cells did not differ significantly in the tumor tissues between the medium $(50 \mathrm{mg} / \mathrm{kg}$ ) and high dosage (100 mg/kg) MLT group (Fig. 1B). The average optical density (OD) of the four groups showed no significant differences ( $P>0.05$, Fig. 1B). Compared with the negative control group, the expression of TGF- $\beta 1$ mRNA in the high dosage $(100 \mathrm{mg} / \mathrm{kg})$ group was significantly increased $(\mathrm{P}<0.05)$, but not in the low $(25 \mathrm{mg} / \mathrm{kg})$ and medium dosage $(50 \mathrm{mg} / \mathrm{kg}$ ) groups (Fig. 1C). Furthermore, compared with the negative control group, TGF- $\beta 1$ concentration in the peripheral serum in the low, medium and high dosage MLT groups was significantly decreased ( $\mathrm{P}<0.05$, Fig. 1D).

Melatonin upregulates the expression of TGF- $\beta 1$ mRNA in MFC gastric cancer cells and TGF- $\beta 1$ inhibits MFC cell proliferation activity. TGF- $\beta 1$ expression was found 
A a

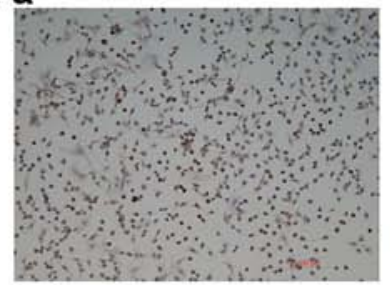

C

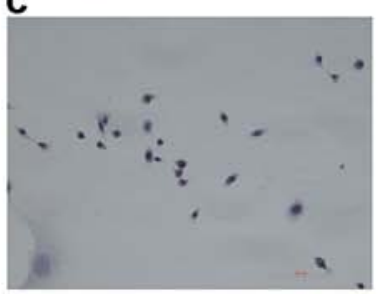

C
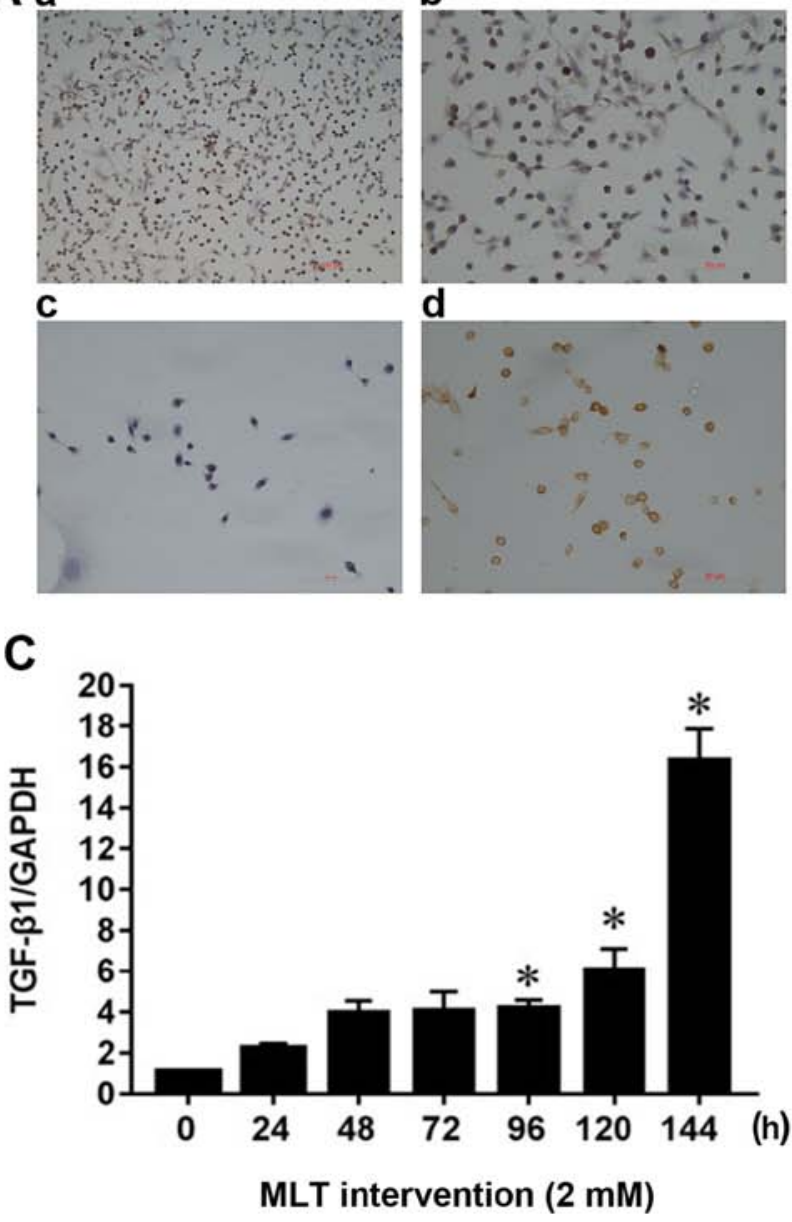

d

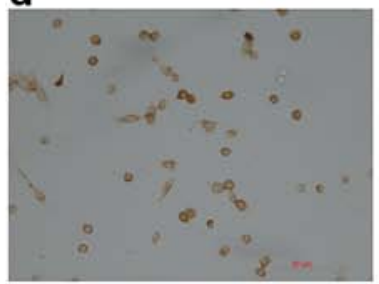

B
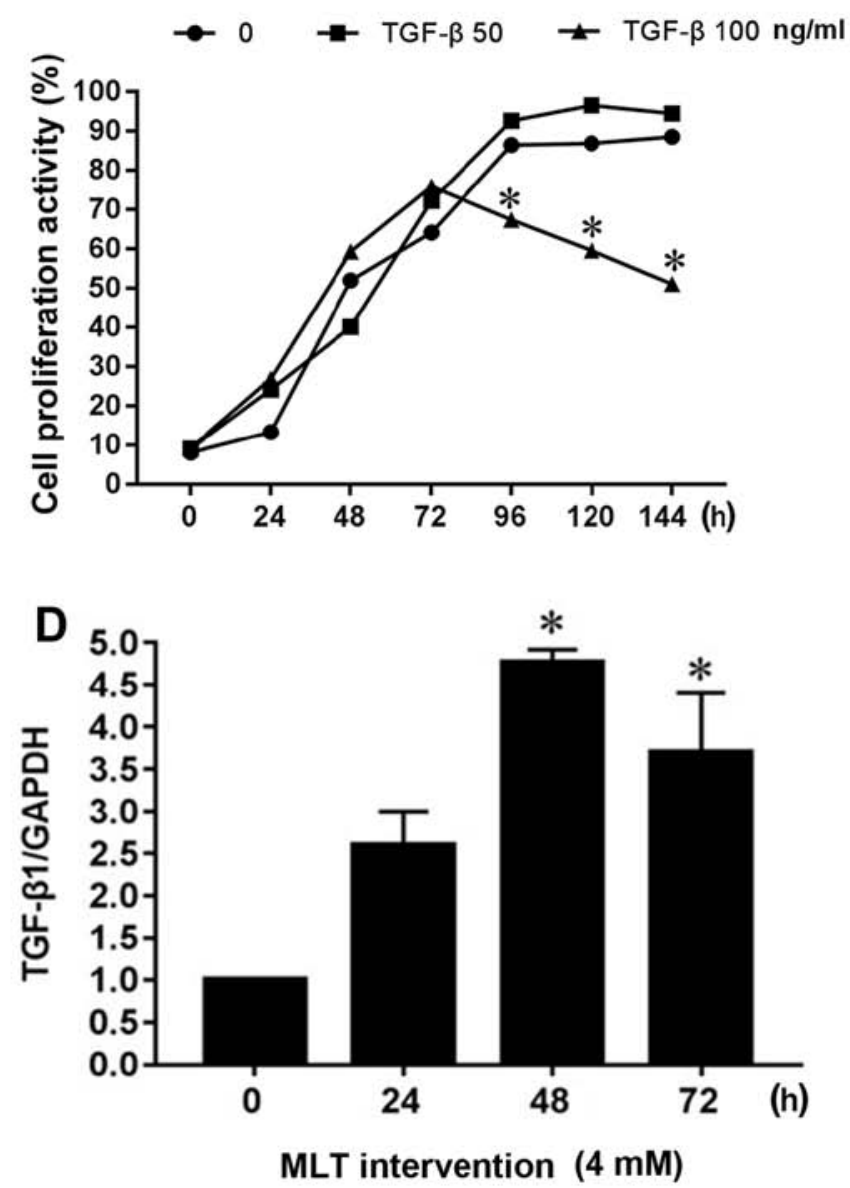

Figure 2. Effect of MLT on TGF- $\beta 1$ expression in MFC cells in vitro and the role of TGF- $\beta 1$ on MFC cell proliferation activity. (A) Expression and location of the TGF- $\beta 1$ protein in MFC cells. ( $a, b$ and d) Obvious yellow particles are present in the cytoplasm; (c) negative control. The nuclei were stained with hematoxylin into a purple-blue color, and no yellow particles were present in the cytoplasm. (a, x200 magnification; b-d, x400 magnification). (B) Role of TGF- $\beta 1$ on MFC cell proliferation activity. Percentage of cell proliferation activity as determined by CCK- 8 assay. (C) Effect of 2 mM MLT on TGF- $\beta 1$ mRNA expression in MFC cells at 6 time-points. (D) Effect of $4 \mathrm{mM}$ MLT on TGF- $\beta 1 \mathrm{mRNA}$ expression in MFC cells at 3 time-points. "P<0.05 vs. the blank control. MLT, melatonin; TGF- $\beta 1$, transforming growth factor $\beta$; CCK-8, Cell Counting Kit-8; mRNA, messenger RNA.

to be positive in MFC cells in vitro (Fig. 2A). In addition, 50 or $100 \mathrm{ng} / \mathrm{ml} \mathrm{TGF}-\beta 1$ protein was added to the cellular supernatant to explore whether TGF- $\beta 1$ affects the proliferation activity of MFC cells. As shown in Fig. 2B, MFC cell growth of the blank control reached a plateau after $96 \mathrm{~h}$, such that the addition of $50 \mathrm{ng} / \mathrm{ml}$ TGF- $\beta 1$ had no significant effect on cell proliferation. However, $100 \mathrm{ng} / \mathrm{ml}$ TGF- $\beta 1$ significantly inhibited cell proliferation in a concentration-dependent manner after $96 \mathrm{~h}$ of cell growth. Compared with the blank control group, the expression of TGF- $\beta 1 \mathrm{mRNA}$ was significantly increased after $96 \mathrm{~h}$ of the $2 \mathrm{mM}$ MLT intervention (Fig. 2C). TGF- $\beta 1 \mathrm{mRNA}$ expression did not change significantly after $24 \mathrm{~h}$ of $4 \mathrm{mM}$ MLT intervention, but after 48 and $72 \mathrm{~h}$, TGF- $\beta 1 \mathrm{mRNA}$ expression increased significantly, peaking after $48 \mathrm{~h}$ of MLT intervention (Fig. 2D); a difference that was statistically significant $(\mathrm{P}<0.05)$.

Anti-TGF- $\beta 1$ neutralizing antibodies inhibit the toxic effect of melatonin in MFC cells. The anti-TGF- $\beta 1$ neutralizing antibody was found to block TGF- $\beta 1$ secretion, thereby inhibiting the toxicity of MLT in the MFC cells. As shown in Fig. 3A, compared with the $0 \mathrm{mM}$ MLT blank control group, cell proliferation activity decreased after $24 \mathrm{~h}$ in the $2 \mathrm{mM}$ MLT group and $2 \mathrm{mM}$ MLT + anti-TGF- $\beta 1$ group $(\mathrm{P}<0.05)$. However, after the addition of the anti-TGF- $\beta 1$ neutralizing antibody, the cell proliferation activity was increased significantly at 120 and $144 \mathrm{~h}$ compared with the $2 \mathrm{mM}$ MLT group $(\mathrm{P}<0.05)$. The results of MLT at a concentration of $4 \mathrm{mM}$ are shown in Fig. 3B. Compared with the $0 \mathrm{mM}$ MLT blank control group, cell proliferation activity was significantly decreased after $24 \mathrm{~h}$ in the $4 \mathrm{mM}$ MLT group and $4 \mathrm{mM}$ MLT + anti-TGF- $\beta 1$ group $(\mathrm{P}<0.05)$, and the effect was time-dependent. The addition of the anti-TGF- $\beta 1$ neutralizing antibody did not affect the toxicity of MLT to MFC cells, and there were no differences between the two groups.

The melatonin-mediated inhibition of the proliferation activity of MFC cells was abrogated by blocking the TGF- $\beta 1$ signaling pathway. Since TGF- $\beta 1$ is a secreted protein, in order to study the effect of partial or complete blockage of the TGF- $\beta 1$ signaling pathway on MLT-induced MFC cell proliferation, both siRNA-mediated TGF- $\beta 1$ silencing and anti-TGF- $\beta 1$ neutralizing antibody were used to block the TGF- $\beta 1$ secretory pathway. The results (Fig. 4A and C) showed that the 

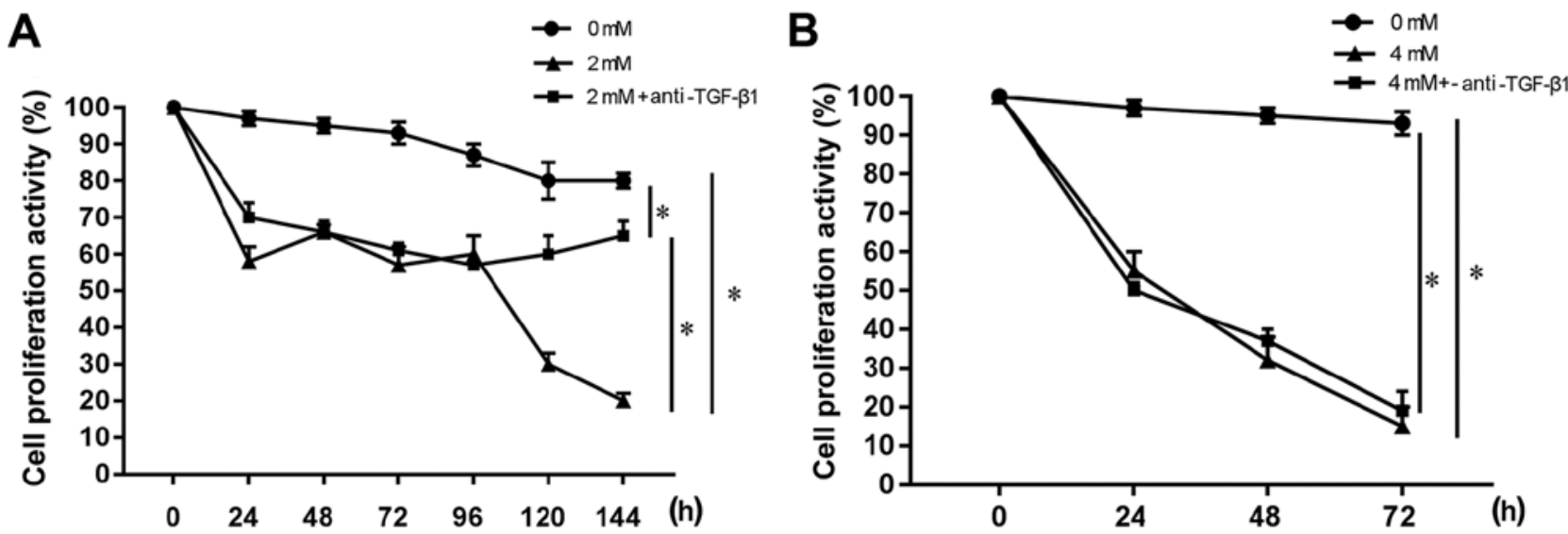

Figure 3. Effect of MLT and anti-TGF- $\beta 1$ neutralization antibody on MFC cell proliferation activity. (A) Effect of 2 mM MLT and anti-TGF- $\beta 1$ neutralization antibody on the cell proliferation activity of MFC cells at 6 time-points. ${ }^{*} \mathrm{P}<0.05$ vs. the $0 \mathrm{mM}$ MLT blank control group. (B) Effect of $4 \mathrm{mM}$ MLT and anti-TGF- $\beta 1$ neutralization antibody on the cell proliferation activity of MFC cells at 3 time-points. ${ }^{*} \mathrm{P}<0.05$ vs. the 0 mM MLT blank control group. MLT, melatonin; TGF- $\beta 1$, transforming growth factor $\beta 1$.

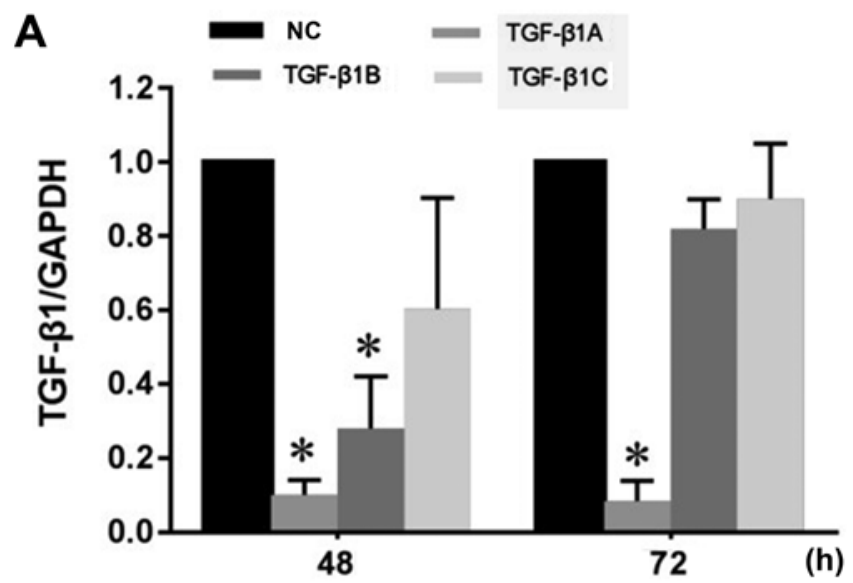

B
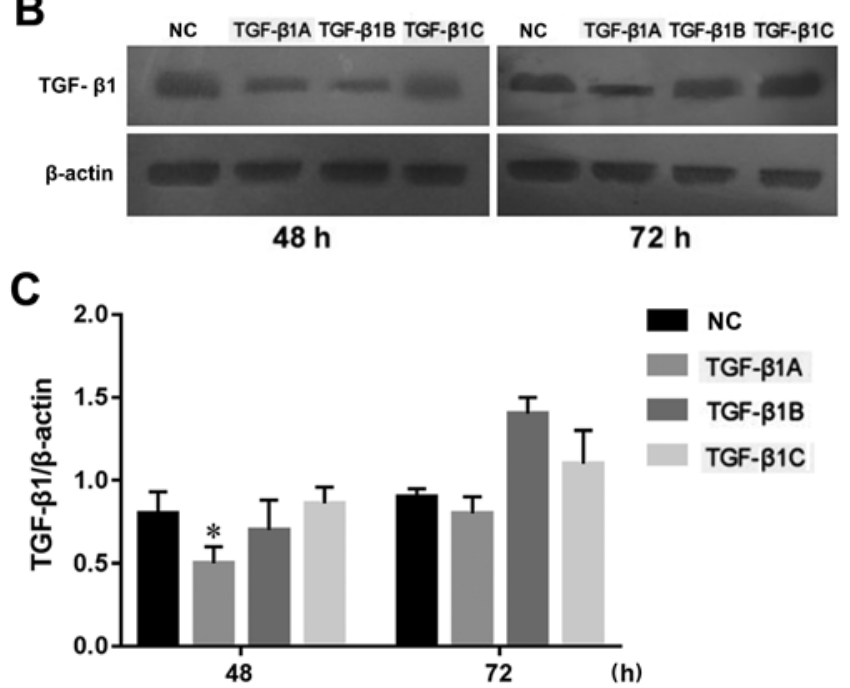

Figure 4. The most effective siRNA-TGF- $\beta 1$ reagent in MFC cells was selected by (A) RT-qPCR and (B and C) western blot analysis. ${ }^{*} \mathrm{P}<0.05$ vs. the negative control. siRNA, small interfering RNA; TGF- $\beta 1$, transforming growth factor $\beta 1$.

expression of TGF- $\beta 1 \mathrm{~A}$ decreased significantly compared with the negative control at $48 \mathrm{~h}$ in MFC cells, thus the siRNA-TGF- $\beta 1 \mathrm{~A}$ reagent was selected for subsequent cellular experiments. Experimental results are shown in Fig. 5. The proliferation activity of the four MFC cell groups [(a1) $2 \mathrm{mM}$ MLT-treated group; (b1) 2 mM MLT + siRNA negative control group; (c1) 2 mM MLT + siRNA TGF- $\beta 1$ group; (d1) $2 \mathrm{mM}$ MLT + siRNA TGF- $\beta 1$ + anti-TGF- $\beta 1$ group] were decreased significantly after $24 \mathrm{~h}$ following $2 \mathrm{mM}$ MLT intervention, and the effect was not time-dependent (Fig. 5A). There was no significant difference in cell viability between groups a1, b1 and c1, while the cell viability of group d1 (2 mM MLT + siRNA TGF- $\beta 1+$ anti-TGF- $\beta 1$ ) differed significantly from the other three groups. After $72 \mathrm{~h}$, the cell proliferation activity of group d1 was significantly increased $(\mathrm{P}<0.05)$. The proliferation activity of the four MFC cell groups [(a2) $4 \mathrm{mM}$ MLT-treated group; (b2) 4 mM MLT + siRNA negative control group; (c2) 4 mM MLT + siRNA TGF- $\beta 1$ group; (d2) $4 \mathrm{mM}$ MLT + siRNA TGF- $\beta 1+$ anti-TGF- $\beta 1$ group] were significantly decreased after $24 \mathrm{~h}$ following $4 \mathrm{mM}$ MLT intervention, and was time-dependent (Fig. 5B). There was no significant difference in cell viability between groups $\mathrm{a} 2$ and b2 $(\mathrm{P}>0.05)$ or between groups c2 and b2 $(\mathrm{P}>0.05)$. However, groups $\mathrm{d} 2$ and $\mathrm{a} 2$ did differ significantly, and in group a2, the cell proliferation activity was significantly increased at 48 and $72 \mathrm{~h}$.

Melatonin-mediated promotion of cell cycle arrest of the $M F C$ cells was antagonized by blocking the TGF- $\beta 1$ signaling pathway. TGF- $\beta 1$ plays an important regulatory role in cell growth and differentiation, thus this study investigated the effect of MLT on the cell cycle of MFC cells when the TGF- $\beta 1$ signaling pathway was partially or completely blocked. The results of the experiment are shown in Fig. 6. Fig. 6A shows that at an MLT concentration of $2 \mathrm{mM}$, at 24,48 and $72 \mathrm{~h}$ time-points, respectively, compared with group a1 and b1, the percentage of $\mathrm{G} 1$ phase cells of the $\mathrm{cl}$ and $\mathrm{d} 1$ groups was significantly lower $(\mathrm{P}<0.05)$, and the percentage of $\mathrm{S}$ phase cells of the $\mathrm{cl}$ and $\mathrm{d} 1$ groups was significantly higher than that of group a1 and b1 control, while the difference in the G2 stage was not significant. There was no significant difference in the cell cycle distribution between group a1 and b1 at the same time-point $(\mathrm{P}>0.05)$. Fig. 6B shows that at an MLT 

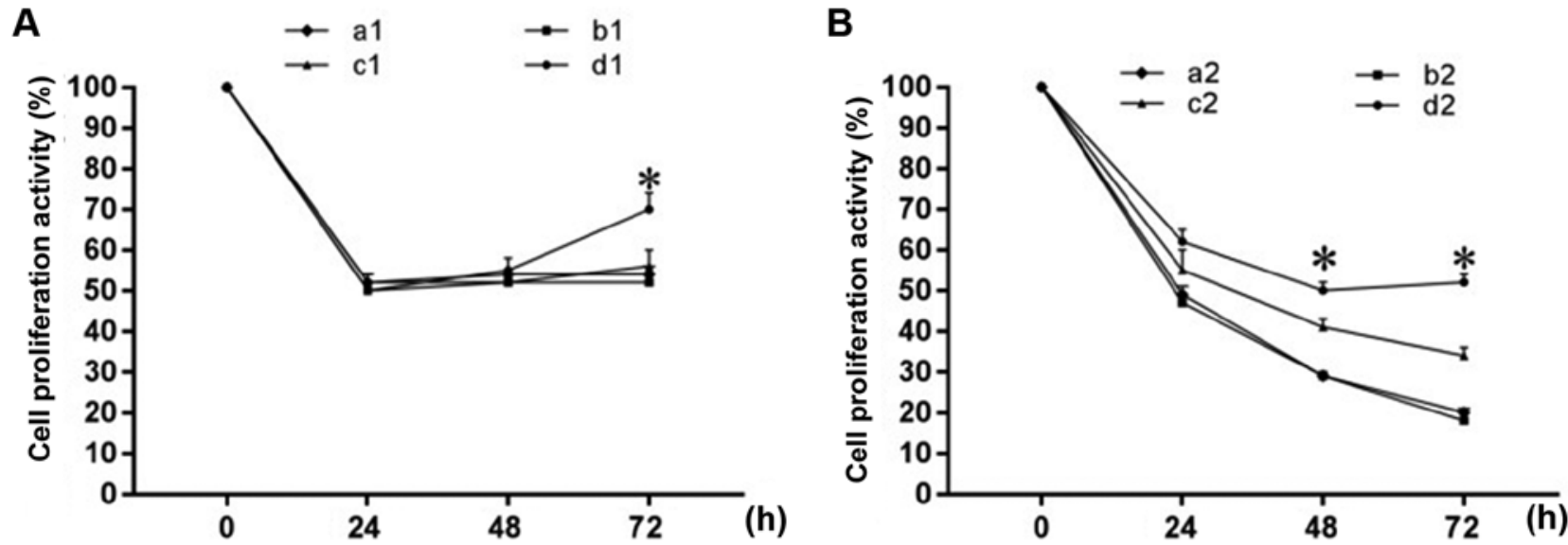

Figure 5. Effect of MLT on MFC cell proliferation activity following obstruction of the TGF- $\beta 1$ signaling pathway. Groups: (A) (a1) $2 \mathrm{mM} \mathrm{MLT,} \mathrm{(b1)} 2 \mathrm{mM}$ MLT + NC, (c1) $2 \mathrm{mM}$ MLT + siRNA TGF- $\beta 1$, (d1) $2 \mathrm{mM} \mathrm{MLT} \mathrm{+} \mathrm{siRNA} \mathrm{TGF- \beta 1} \mathrm{+} \mathrm{anti-TGF- \beta 1.} \mathrm{(B)} \mathrm{(a2)} 4 \mathrm{mM}$ MLT, (b2) $4 \mathrm{mM} \mathrm{MLT} \mathrm{+} \mathrm{NC,} \mathrm{(c2)} 4 \mathrm{mM}$ MLT + siRNA TGF- $\beta 1$, (d2) 4 mM MLT+ siRNA TGF- $\beta 1+$ anti-TGF- $\beta 1$. Percentage of cell proliferation activity was determined by CCK- 8 assay. ${ }^{*} \mathrm{P}<0.05$ vs. the control group. MLT, melatonin; TGF- $\beta 1$, transforming growth factor $\beta 1$; NC, negative control; siRNA, small interfering RNA; CCK-8, Cell Counting Kit-8.

A
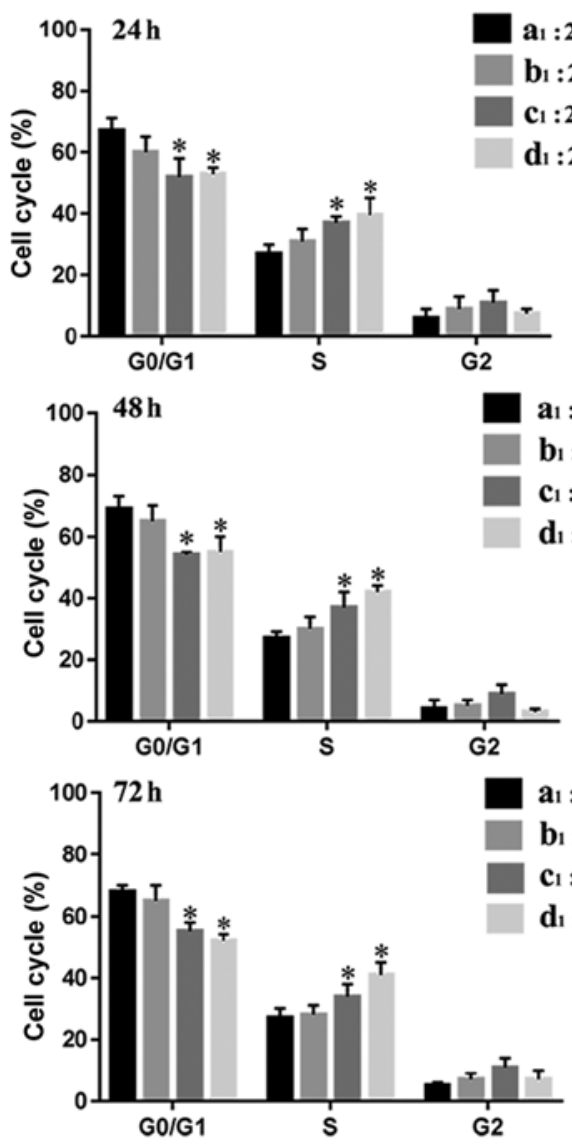

B
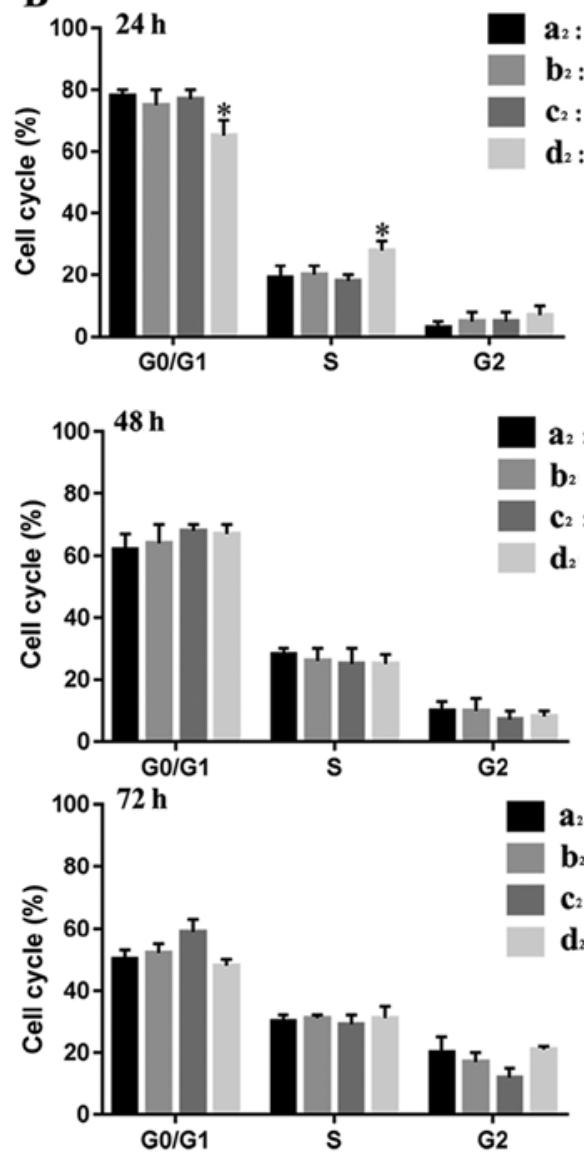

$\mathrm{a}_{2}: 4 \mathrm{mM}$

$\mathrm{b}_{2}: 4 \mathrm{mM}+\mathrm{NC}$

$c_{2}: 4 \mathrm{mM}+$ TGF- $\beta 1 \mathrm{~A}$

$\mathrm{d}_{2}: 4 \mathrm{mM}+\mathrm{TGF}-\beta 1 \mathrm{~A}+$ anti

$a_{2}: 4 \mathrm{mM}$

$b_{2}: 4 \mathrm{mM}+\mathrm{NC}$

$c_{2}: 4 \mathrm{mM}+\mathrm{TGF}-\beta 1 \mathrm{~A}$

$d_{2}: 4 \mathrm{mM}+\mathrm{TGF}-\beta 1 \mathrm{~A}+$ anti

$\mathrm{a}_{2}: 4 \mathrm{mM}$

$b_{2}: 4 \mathrm{mM}+\mathrm{NC}$

$c_{2}: 4 \mathrm{mM}+\mathrm{TGF}-\beta 1 \mathrm{~A}$

$\mathrm{d}_{2}: 4 \mathrm{mM}+\mathrm{TGF}-\beta 1 \mathrm{~A}+$ anti

Figure 6. Effect of MLT on the cell cycle distribution of MFC cells following obstruction of the TGF- $\beta 1$ signaling pathway at 24,48 and $72 \mathrm{~h}$. (A) Groups: (a1) 2 mM MLT, (b1) 2 mM MLT + NC, (c1) 2 mM MLT + siRNA TGF- $\beta 1$, (d1) 2 mM MLT + siRNA TGF- $\beta 1$ + anti-TGF- $\beta 1$. (B) Groups: (a2) 4 mM MLT, (b2) 4 mM MLT + NC, (c2) 4 mM MLT + siRNA TGF- $\beta 1$, (d2) 4 mM MLT + siRNA TGF- $\beta 1$ + anti-TGF- $\beta 1$. " $\mathrm{P}<0.05$ vs. the control group. MLT, melatonin; TGF- $\beta 1$, transforming growth factor $\beta 1$; NC, negative control; siRNA, small interfering RNA.

concentration of $4 \mathrm{mM}$, at the $24 \mathrm{~h}$ time-point, the percentage of cells in the $\mathrm{d} 2$ group in $\mathrm{S}$ phase was significantly higher than that of the other three groups, and the percentage of cells in the G1 phase was significantly lower $(\mathrm{P}<0.05)$, while the G2 phase was not significantly different. The effect of MLT on the other three groups (a2, b2 and c2) was not significantly different at the same time-point. At the 48 and $72 \mathrm{~h}$ time-points, respectively, there were no significantly differences in the cell cycle distribution between the four groups at the same time-point. 


\section{Discussion}

TGF- $\beta$ is a polypeptide growth factor with various biological activities, and regulates a number of processes such as cell proliferation and differentiation, metastasis, neovascularization, and immunosuppression. Any abnormality in the TGF- $\beta$ signaling pathway induces tumor growth. Previous studies $(23,24)$ have shown that TGF- $\beta 1$ acts as a tumor suppressor in the early stages of normal epithelial cell growth and tumorigenesis, and acts as a tumor promoter during malignant progression. These different effects may be due to an early immune response that results in the secretion of a large amount of TGF- $\beta 1$ to prevent the transformation of normal cells into tumor cells. However, the loss of TGF- $\beta 1$ receptor expression or loss of function at a later stage allows tumor cells to escape the growth inhibition of TGF- $\beta 1$, resulting in tumor cell proliferation. Studies have shown that TGF- $\beta 1$-induced gastric epithelial-mesenchymal transition (EMT) can promote the invasion and metastasis of gastric cancer cells in vitro (25-28).

This study demonstrated that a high concentration of melatonin (MLT) increases TGF- $\beta 1$ gene expression in tumor tissue. The main roles of TGF- $\beta 1$ in a healthy organism are to inhibit epithelial-derived cell growth, regulate the immune response, and suppress immune function. The mouse MFC gastric cancer cell line is an epithelial-derived cell line. It has been shown that most epithelial-derived tumors are resistant to TGF- $\beta 1$-induced cell growth inhibition, and this occurrence of tolerance is considered to be an important step in the development of malignant cells. A high concentration of MLT can increase the secretion of TGF- $\beta 1$ in tumor tissue, and as such inhibit normal benign epithelial cells from transforming into malignant cells, and prevent the invasion and metastasis of malignant cells $(29,30)$. In addition, in vivo experiments have shown that the concentration of TGF- $\beta 1$ in the serum of mice with gastric cancer is significantly increased, and administration of MLT reduces it to a normal level. Other studies have also found that the concentration of TGF- $\beta 1$ in serum of patients with early and advanced gastric cancer is significantly higher than that of healthy controls $(24,31)$.

In vitro experiments showed that a low concentration $(2 \mathrm{mM})$ of MLT significantly decreased the proliferation activity of MFC cells after $96 \mathrm{~h}$ of intervention, and the expression of TGF- $\beta 1 \mathrm{mRNA}$ was upregulated, and this effect was antagonized by anti-TGF- $\beta 1$ neutralizing antibody. A high concentration $(4 \mathrm{mM})$ of MLT significantly decreased the proliferation of MFC cells after only $24 \mathrm{~h}$. After $48 \mathrm{~h}$ of intervention, the expression of TGF- $\beta 1$ mRNA was upregulated, but it could not be inhibited by anti-TGF- $\beta 1$ neutralizing antibody. At the same time, it was found that the proliferation of gastric cancer cells was significantly inhibited by adding $100 \mathrm{ng} / \mathrm{ml}$ TGF- $\beta 1$ to the supernatant of MFC cells for $96 \mathrm{~h}$. Furthermore, anti-TGF- $\beta 1$ neutralizing antibody was found to inhibit the secretion of TGF- $\beta 1$ in the supernatant. A prior study also found that MLT inhibited TGF $\beta 1$-induced epithelial-mesenchymal transition in the A549 human alveolar epithelial cell line (32).

Neutralizing antibodies, especially monoclonal antibodies, are commonly used to block the secretion of TGF- $\beta 1$ in tumor cells. To investigate the role of TGF- $\beta 1$ in the MLT-mediated inhibition of the proliferation of gastric cancer cells, we partially or completely blocked TGF- $\beta 1$ secretion, and divided cells into four groups: MLT-treated group, MLT + saline group, MLT + TGF- $\beta 1$ siRNA group, and MLT + TGF- $\beta 1$ siRNA + anti-TGF- $\beta 1$ group. The result showed that partial blocking did not antagonize the inhibition of MLT on the proliferation of gastric cancer cells over a short period, and the combination of TGF- $\beta 1$ siRNA and anti-TGF- $\beta 1$ completely blocked TGF- $\beta 1$ signaling in MFC cells and restored the proliferative activity. Wang et al (33) transfected TGF- $\beta 1$ siRNA into the breast cancer cell line MDA-231 to inhibit the expression of TGF- $\beta 1$. The results showed that the migration, invasion, and angiogenesis of tumor cells were significantly reduced in vitro. TGF- $\beta 1$ siRNA/MDA- 231 cells treated with $5 \mathrm{ng} / \mathrm{ml}$ TGF- $\beta 1$ for $24 \mathrm{~h}$ exhibited restored tumor cell invasive ability. TGF- $\beta 1$ treatment did not increase migration, invasion, or angiogenesis in the TGF- $\beta 1$ siRNA/MDA-231 cells when treated with $25 \mu \mathrm{M}$ PD98059 or transfected with S100A4 siRNA before TGF- $\beta 1$ treatment, which is similar to our findings.

The $4 \mathrm{mM}$ MLT-treated group showed a significant difference after $48 \mathrm{~h}$, while the cell viability of the $2 \mathrm{mM}$ MLT-treated group recovered within $72 \mathrm{~h}$ of dosing. The proliferative state of cells is related to the cell cycle. The transition from G1 phase to $\mathrm{S}$ phase is an important checkpoint of cell cycle regulation. A cell that is blocked in G1 phase or G2 phase enters $S$ phase for a prolonged time, resulting in the inhibition of cell proliferation (34). Therefore, in this study we observed cell cycle changes and found that siRNA-mediated TGF- $\beta 1$ silencing for 24,48 and $72 \mathrm{~h}$, respectively, significantly increased the $S$ phase duration of MFC cells inhibited by a low concentration of MLT, while significantly shortening the G1 phase which resulted in an increase in cell proliferation. After $24 \mathrm{~h}$ of combined application, the combination of a high concentration of MLT inhibited the cell cycle, and the population of S phase MFC cells was significantly increased, and the cell activity was increased. Similar to previous studies (16), cell growth was inhibited by MLT treatment in a time-dependent manner, and MLT effectively blocked human gastric cancer MFC cells in the G1/S phase of the cell cycle.

In conclusion, MLT inhibits the proliferation of gastric cancer cells in vitro and in vivo by increasing the expression of TGF- $\beta$. siRNA-mediated TGF- $\beta 1$ silencing and anti-TGF- $\beta 1$ neutralizing antibody completely blocked the TGF- $\beta 1$ pathway, and significantly antagonized the MLT-mediated inhibition of the growth and proliferation of gastric cancer cells in a short period, which increased the cell proliferation activity and promoted the transition from G1 phase to S phase of gastric cancer cells, suggesting that TGF- $\beta 1$ is involved in the regulation of proliferation of tumor cells. One of the pathways involved in the MLT-mediated inhibition of gastric cancer cells is the TGF- $\beta 1$ signaling pathway.

\section{Acknowledgements}

Not applicable.

\section{Funding}

The present study was supported by the Natural Science Foundation of Fujian Provincial Department of Science and Technology (nos. 2017J01530 and 2016J01535); the Key and 
Guide Project of Science and Technology Commission of Fujian Province of China (no. 2018Y0039); the National Natural Sciences Foundation Projects of China (no. 81302601); the Young and Middle-Aged Key Personnel Training Program of Fujian Provincial Health and Family Planning Commission (no. 2016-ZQN-51); the Special Funds for Education and Scientific Research of Fujian Provincial Department of Finance (no. 2018B012).

\section{Availability of data and materials}

The datasets used during the present study are available from the corresponding author upon reasonable request.

\section{Authors' contributions}

RXZ was involved in the study concept, design and supervision and provided final approval of the version to be published. HL was involved in the drafting of the manuscript, the analysis and interpretation of the data, performed the experiments and obtained funding. $\mathrm{YZ}, \mathrm{HZ}$ and $\mathrm{RC}$ were involved in performing the experiments, the analysis and interpretation of the data. KFW, JS and RXW assisted with the experimental design, the data interpretation and acquisition of funding. All authors read and approved the final manuscript and agree to be accountable for all aspects of the research in ensuring that the accuracy or integrity of any part of the work are appropriately investigated and resolved.

\section{Ethics approval and consent to participate}

All experimental protocols were approved by the Fujian Medical University Animal Welfare and Ethics Committee provided approval for this study (FJMUIACUC2018-003), which is located in Fuzhou, Fujian Province, China.

\section{Patient consent for publication}

Not applicable.

\section{Competing interests}

The authors state that they have no competing interests.

\section{References}

1. Torre LA, Bray F, Siegel RL, Ferlay J, Lortet-Tieulent J and Jemal A: Global cancer statistics, 2012. CA Cancer J Clin 65 : 87-108, 2015.

2. Sano T, Coit DG, Kim HH, Roviello F, Kassab P, Wittekind C, Yamamoto Y and Ohashi Y: Proposal of a new stage grouping of gastric cancer for TNM classification: International Gastric Cancer Association staging project. Gastric Cancer 20: 217-225, 2017.

3. Bbenik GA: Localization, physiological significance and possible clinical implication of gastrointestinal melatonin. Biol Signals Recept 10: 350-366, 2001.

4. Slominski AT, Zmijewski MA, Semak I, Kim TK, Janjetovic Z, Slominski RM and Zmijewski JW: Melatonin, mitochondria, and the skin. Cell Mol Life Sci 74: 3913-3925, 2017.

5. Slominski AT, Hardeland R, Zmijewski MA, Slominski RM, Reiter RJ and Paus R: Melatonin: A cutaneous perspective on its production, metabolism, and functions. J Invest Dermatol 138: 490-499, 2018
6. Slominski RM, Reiter RJ, Schlabritz-Loutsevitch N, Ostrom RS and Slominski AT: Melatonin membrane receptors in peripheral tissues: Distribution and functions. Mol Cell Endocrinol 351: 152-166, 2012.

7. Li T, Ni L, Zhao Z, Liu X, Lai Z, Di X, Xie Z, Song X, Wang X, Zhang $\mathrm{R}$ and Liu C: Melatonin attenuates smoking-induced hyperglycemia via preserving insulin secretion and hepatic glycogen synthesis in rats. J Pineal Res 64: e12475, 2018.

8. Li Y, Li S, Zhou Y, Meng X, Zhang JJ, Xu DP and Li HB Melatonin for the prevention and treatment of cancer. Oncotarget 8: 39896-39921, 2017.

9. Wei X, Qi Y, Jia N, Zhou Q, Zhang S and Wang Y: Hyperbaric oxygen treatment sensitizes gastric cancer cells to melatonin-induced apoptosis through multiple pathways. J Cell Biochem 119: 6723-6731, 2018.

10. Zhang S, Qi Y, Zhang H, He W, Zhou Q, Gui S and Wang Y: Melatonin inhibits cell growth and migration, but promotes apoptosis in gastric cancer cell line, SGC7901. Biotech Histochem 88: 281-289, 2013.

11. Ordoñez R, Carbajo-Pescador S, Prieto-Dominguez N, García-Palomo A, González-Gallego J and Mauriz JL: Inhibition of matrix metalloproteinase 9 and nuclear factor kappa B contribute to melatonin prevention of motility and invasiveness in HepG2 liver cancer cells. J Pineal Res 56: 20-30, 2014.

12. Proietti S, Cucina A, Dobrowolny G, D'Anselmi F, Dinicola S, Masiello MG, Pasqualato A, Palombo A, Morini V, Reiter RJ and Bizzarri M: Melatonin downregulates MDM2 gene expression and enhances p53 acetylation in MCF-7 cells. J Pineal Res 57: 120-129, 2014.

13. Cutando A, López Valverde A, De Vicente J, Gimenez JL, Carcía IA and DE Diego RG: Action of melatonin on squamous cell carcinoma and other tumors of the oral cavity (Review). Oncol Lett 7: 923-926, 2014.

14. Liu H, Xu L, Wei JE, Xie MR, Wang SE and Zhou RX: Role of $\mathrm{CD} 4^{+} \mathrm{CD} 25^{+}$regulatory $\mathrm{T}$ cells in melatonin-mediated inhibition of murine gastric cancer cell growth in vivo and in vitro. Anat Rec (Hoboken) 294: 781-788, 2011.

15. Wang RX, Liu H, Xu L, Zhang H and Zhou RX: Melatonin downregulates nuclear receptor RZR/ROR $\gamma$ expression causing growth-inhibitory and anti-angiogenesis activity in human gastric cancer cells in vitro and in vivo. Oncol Lett 12: 897-903, 2016.

16. Song J, Ma SJ, Luo JH, Zhang H, Wang RX, Liu H,Li L, Zhang ZG and Zhou RX: Melatonin induces the apoptosis and inhibits the proliferation of human gastric cancer cells via blockade of the AKT/MDM2 pathway. Oncol Rep 39: 1975-1983, 2018.

17. Liu H, Jiang JH, Xu L, Gong X and Zhou RX: Proliferation inhibition and apoptosis induction of melatonin in mouse MFC progastric cells in vitro and in vivo. Chin J Anat 42: 794-799, 2011.

18. Patil AS, Sable RB and Kothari RM: An update on transforming growth factor- $\beta$ (TGF- $\beta$ ): Sources, types, functionsand clinical applicability for cartilage/bone healing. J Cell Physiol 226: 3094-3103, 2011.

19. Pickup M, Novitskiy S and Moses HL: The roles of TGF $\beta$ in the tumour microenvironment. Nat Rev Cancer 13: 788-799, 2013.

20. Proietti S, Cucina A, D'Anselmi F, Dinicola S, Pasqualato A, Lisi E and Bizzarri M: Melatonin and vitamin D3 synergistically down-regulate Akt and MDM2 leading to TGF $\beta$-1-dependent growth inhibition of breast cancer cells. J Pineal Res 50: 150-158, 2011.

21. Xu L, Liu H, Zhang H, Wang RX, Song J and Zhou RX: Growth-inhibitory activity of melatonin on murine foregastric carcinoma cells in vitro and the underlying molecular mechanism. Anat Rec (Hoboken) 296: 914-920, 2013.

22. Livak KJ and Schmittgen TD. Analysis of relative gene expression data using real-time quantitative PCR and the 2(-Delta Delta C(T)) method. Methods 25: 402-408, 2001

23. Liang X, Liang X, Zeng J, Wang L, Shen L, Ma X, Li S, Wu Y, Ma L, Ci X, et al: Histone demethylase RBP2 promotes malignant progression of gastric cancer through TGF- $\beta 1-(\mathrm{p}-\mathrm{Smad} 3)-$ RBP2-E-cadherin-Smad3 feedback circuit. Oncotarget 6: 17661-17674, 2015.

24. Tas F, Yasasever CT, Karabulut S, Tastekin D and Duranyildiz D: Serum transforming growth factor-beta1 levels may have predictive and prognostic roles in patients with gastric cancer. Tumour Biol 36: 2097-2103, 2015.

25. Li C, Song L,Zhang Z, Bai XX, Cui MF and Ma LJ: MicroRNA-21 promotes TGF- $\beta 1$-induced epithelial-mesenchymal transition in gastric cancer through up-regulating PTEN expression. Oncotarget 7: 66989-67003, 2016. 
26. Gen Y, Yasui K, Kitaichi T, Iwai N, Terasaki K, Dohi O, Hashimoto H, Fukui H, Inada Y, Fukui A, et al: ASPP2 suppresses invasion and TGF- $\beta 1$-induced epithelial-mesenchymal transition by inhibiting Smad7 degradation mediated by E3 ubiquitin ligase ITCH in gastric cancer. Cancer Lett 398: 52-61, 2017.

27. Zhu J and Wen K: Astragaloside IV inhibits TGF- $\beta 1$-induced epithelial- mesenchymal transition through inhibition of the $\mathrm{PI} 3 \mathrm{~K} / \mathrm{Akt} / \mathrm{NF}-\kappa \mathrm{B}$ pathway in gastric cancer cells. Phytother Re 32: 1289-1296, 2018.

28. Ma HY, Liu XZ and Liang CM: Inflammatory microenvironment contributes to epithelial-mesenchymal transition in gastric cancer. World J Gastroenterol 22: 6619-6628, 2016.

29. Gonzalez-Moreno O, Lecanda J, Green JE, Segura V, Catena R, Serrano D and Calvo A: VEGF elicits epithelial-mesenchymal transition (EMT) in prostate intraepithelial neoplasia (PIN)-like cells via an autocrine loop. Exp Cell Res 316: 554-567, 2010.
30. Wu Q, Hou X, Xia J, Qian X, Miele L, Sarkar FH and Wang Z: Emerging roles of PDGF-D in EMT progression during tumorigenesis. Cancer Treat Rev 39: 640-646, 2013.

31. Ma GF, Miao Q, Zeng XQ, Luo TC, Ma LL, Liu YM, Lian JJ, Gao $H$ and Chen SY: Transforming growth factor- $\beta 1$ and $-\beta 2$ in gastric precancer and cancer and roles in tumor-cell interactions with peripheral blood mononuclear cells in vitro. PLoS One 8: e54249, 2013

32. Yu N, Sun YT, Su XM, He M, Dai B and Kang J: Melatonin attenuates TGF $\beta 1$-induced epithelial-mesenchymal transition in lung alveolar epithelial cells. Mol Med Rep 14: 5567-5572, 2016.

33. Wang XG, Meng Q, Qi FM and Yang QF: Blocking TGF- $\beta$ inhibits breast cancer cell invasiveness via ERK/S100A4 signal. Eur Rev Med Pharmacol Sci 18: 3844-3853, 2014.

34. Chatterjee A, Mukhopadhyay S, Tung K, Patel D and Foster DA: Rapamycin-induced G1 cell cycle arrest employs both TGF- $\beta$ and $\mathrm{Rb}$ pathways. Cancer Lett 360: 134-140, 2015. 